\title{
Margaret McCartney: Juniors vote to strike-a profession united for the NHS
}

\author{
Margaret McCartney general practitioner, Glasgow
}

In the ballot on strike action, junior doctors voted almost unanimously in favour (98\% of 28305 ; response rate $76 \%$ ). ${ }^{1}$ Consultants are offering their full support. GPs have been marching alongside.

Jeremy Hunt's biggest success as health secretary has been to unite the medical profession-against him. What's next? I wish that the Department of Health would sit down with the Advisory, Conciliation and Arbitration Service and the BMA.

Not all of the vast media coverage on this row has been accurate. The BMA, despite wanting the threat of imposition of contract removed, has told me that it is not insisting on the removal of other preconditions as a prelude to talks (that is, the 22

recommendations of the Review Body on Doctors' and Dentists' Remuneration $^{2}$ ).

And, clearly, Hunt has presented statistics to tell the story he wants to tell, whether it's about weekend care ${ }^{3}$ or consultant cover. ${ }^{4}$ Policy based on biased numbers cannot benefit patients. But we shouldn't see this row in isolation. The US commentator Noam Chomsky described a "standard technique of privatisation: defund, make sure things don't work, people get angry, you hand it over to private capital . . . If it can be privatised it's a huge bonanza for investors ... And as usual when the system crashes, going back to the taxpayer to bail them out." ${ }^{, 5}$

Remember Hinchingbrooke Hospital. It was run by the stock market listed company Circle until it left its contract early, citing funding and social care cuts and increases in emergency attendances, ${ }^{6}$ and requesting a $£ 10 \mathrm{~m}(€ 14.3 \mathrm{~m} ; \$ 15.3 \mathrm{~m})$ bailout from taxpayers as it went. ${ }^{7}$

Chomsky was correct, and the dispute with juniors has got the vultures circling. The Department of Health has framed its row with juniors on erroneous statistics but has told the public that it's all about obtaining a "truly seven day" NHS. We already have one, of course, but one based on need rather than want.

In the political—and truly unevidenced-NHS, the Department of Health continues to flush money away on things that simply don't work. It has failed to show cost effectiveness for private finance initiative contracts, Choose and Book, health checks, telehealth, dementia screening, and so on.
The NHS lolls from one financial crisis to another, but these were not caused by junior doctors. Juniors are essentially being offered a contract with more unsocial hours for less money and with no effective restrictions. ${ }^{8}$ Junior doctors should not have to take a hit because the Department of Health doesn't understand evidence based medicine-or why health needs should come above wants.

Juniors will vote with their feet. The NHS will become more unsafe. It will be said to have failed. This dispute may represent a turning point: what do we want to spend money on in the NHS? And whose evidence will we choose to believe?

Competing interests: I have read and understood the BMJ policy on declaration of interests and declare the following interests: I'm an NHS GP partner, with income partly dependent on Quality and Outcomes Framework points. I've written two books and earn from broadcast and written freelance journalism. I'm an unpaid patron of Healthwatch. I make a monthly donation to Keep Our NHS Public. I'm a member of Medact. I'm occasionally paid for time, travel, and accommodation to give talks or have locum fees paid to allow me to give talks but never for any drug or public relations company. I was elected to the national council of the Royal College of General Practitioners in 2013 and am chair of its standing group on overdiagnosis. I have invested a small amount of money in a social enterprise, Who Made Your Pants? Provenance and peer review: Commissioned; not externally peer reviewed.

Follow Margaret on Twitter, @mgtmccartney

Rimmer A. Overwhelming majority of junior doctors vote for strike action. $B M J$ 2015;351:h6270

2 Rimmer A. Hunt says there are no preconditions to junior contract negotiations. BMJ Careers 2015 Nov 18. http://careers.bmj.com/careers/advice/Hunt_says_there_are_no_ preconditions to junior contract negotiations.

3 Rimmer A, Kmietowicz Z. BMJ editor writes to Hunt over misuse of weekend mortality data. BMJ 2015;351:h5624.

4 Kirkland F, Campbell D. Jeremy Hunt statement on weekend hospital care is misleading, experts warn. Guardian 2015 Nov 19. www.theguardian.com/society/2015/nov/18/jeremyhunt-statement-on-nhs-weekend-hospital-care-is-misleading-experts-warn.

5 Chomsky $N$. The state-corporate complex: a threat to freedom and survival. Text of lecture given at the University of Toronto, 7 April 2011. http://chomsky.info/20110407-2/.

6 lacobucci G. Private company says it can no longer run NHS hospital. BMJ 2015;350:h159

7 Plimmer G. First privately run NHS hospital seeks $£ 10 \mathrm{~m}$ taxpayer bailout. FT $2015 \mathrm{Feb}$ 9.

8 BMA. Removal of vital safeguards. http://bma.org.uk/working-for-change/in-depth-juniorand-consultant-contract/ddrb-recommendations-analysis-for-juniors/removal-of-vitalsafeguards. 
